\title{
SOME CONSIDERATIONS ON HORIZONTAL DISPLACEMENT AND HORIZONTAL DISPLACEMENT COEFFICIENT $B$
}

\author{
KRZYSZTOF TAJDUŚ \\ Strata Mechanics Research Institute, Polish Academy of Sciences in Cracow
}

ANTONI TAJDUŚ

AGH University of Science and Technology in Cracow

\begin{abstract}
Mining-induced deformations of the ground surface and within the rock mass may pose danger not only for surface constructions but also for underground objects (e.g., tunnels, underground storages, garages), diverse types of pipelines, electric cables, etc. For a proper evaluation of hazard for surface and underground objects, such parameters as horizontal displacement and horizontal deformations, especially their maximum values, are of crucial importance. The paper is an attempt at a critical review of hitherto accomplished studies and state of the art of predicting horizontal displacement $u$, in particular the coefficient $B$, whose value allows determination of the value of maximum displacement if the value of maximum slope is known, or the value of maximum deformation if the value of maximum trough slope is recognized. Since the geodesic observations of fully developed subsidence troughs suggest that the value of the coefficient depends on the depth $H$, radius of main influences range $r$ and properties of overburden rock, in particular the occurrence of sub-eras Paleogene and Neogene layers (old name: Quaternary and Tertiary) with low strength parameters, therefore a formula is provided in the present paper allowing for the estimation of the influence of those factors on the value of coefficient $B$.
\end{abstract}

Key words: horizontal displacement coefficient, horizontal displacement, minig exploitation

\section{INTRODUCTION}

Underground exploitation of natural resources causes the occurrence of deformation both on the surface of the terrain and within the rock mass. Surface deformations may pose danger for surface objects, whereas deformations within the rock mass often lead to the damage of mining excavations, underground objects (tunnels, underground storages, garages), various types of pipelines, electric cables, etc., existing in their range of influence. Therefore, a careful selection of appropriate deformation theory, as well as a proper estimation of parameters of the selected deformation theory, is of crucial importance in this respect. Such a selection allows for a proper determination of deformation coefficients, whose values constitute the measure of hazard. The most important deformation indices include: horizontal displacement $u_{x}$, $u_{y}$, vertical displacement $w$, slope $T_{x}, T_{y}$, horizontal deformation $\varepsilon_{x}, \varepsilon_{y}$, vertical deformation $\varepsilon_{z}$ and curvatures $K_{x}, K_{y}$. It is commonly believed that horizontal displacement and horizontal deformations, especially their maximum values, are most crucial for hazard evaluation for surface objects. The primary objective of the present paper is a critical review of the hitherto executed essential studies and the state-of-the-art in the field of horizontal displacement prediction research, in particular the analyses on the coefficient $B$ of horizontal deformation.

\section{CORRELATION BETWEEN THE COMPONENTS OF SLOPE OF SUBSIDENCE TROUGH PROFILE AND THE COMPONENTS OF HORIZONTAL DISPLACEMENT}

In general, the correlation between the components of slope of subsidence trough profile and the components of horizontal displacement (Avershyn [6], Litwiniszyn [13]) may be presented in the following way 


$$
\begin{aligned}
& u_{x}=\frac{B(x, y, z) \partial w}{\partial x}=B(x, y, z) \cdot T_{x}, \\
& u_{y}=\frac{D(x, y, z) \partial w}{\partial y}=D(x, y, z) \cdot T_{y}
\end{aligned}
$$

where $D(x, y, z), B(x, y, z)$ - coefficients of horizontal displacement.

The coefficients depend upon the following: coordinates $(x, y, z)$ of the point at which displacement is determined, time $(t)$, geological structure, physical and mechanical properties of the analyzed rock mass.

In his research, Litwiniszyn [13] assumed that the rock mass is homogeneous in horizontal planes and invariable in time. He also assumed that for a given rock mass the coefficients $B$ and $D$ are equal and depend only on the variable $z$.

$$
B(z)=D(z) .
$$

The above leads to a conclusion that: $u_{x}=B(z) \cdot T_{x}$, $u_{y}=B(z) \cdot T_{y}$.

A detailed analysis of measurements carried out in the surface of various mines $(z=H)$ indicates that:

(a) due to heterogeneity of rock medium, in numerous cases there is no equality of coefficients $B(z) \neq \cdot D(z) ;$

(b) even if we assume the equality of coefficients, the coefficient $B(z)$ still depends upon the position of the point, i.e., $B(x, y, z)$. It may happen, however, that beyond the contour of exploitation, horizontal displacements are larger than vertical displace- ments, which causes the increase of the value of coefficient $B(x, y, z)$ even above $1.0 r$. Since the surface buildings are usually outside the contour of exploitation, while solving the problems pertaining to building protection, we should know not only the maximum values of displacement and deformation, but also the values of those parameters at any point of the subsidence trough. Additionally, we should also know the character of distribution of displacement and deformation in the trough.

Avershyn [6] estimated the value of coefficient $B$ from the value of maximum slope

$$
u_{\max }=B \cdot T_{\max } .
$$

The value of coefficient $B$ can also be estimated from the value of maximum deformation

$$
\varepsilon_{\max }=B \cdot K_{\max } \cdot
$$

On the basis of his analyses, Avershyn argued that the value of coefficient $B$ in the surface ranges between $B=5 \mathrm{~m}-20 \mathrm{~m}$, whereas in the majority of cases this range is narrower, i.e., $B=10 \mathrm{~m}-12 \mathrm{~m}$.

In Poland, Budryk-Knothe theory is commonly applied in predicting rock mass deformation above the mined-out deposits. The essential parameters of this theory include: maximum subsidence $w_{\max }$, angle of main influences $\beta$, radius $r$ of main influences' range, depth $H$ and horizontal deformation coefficient $B$.

In the 1960s, also Sałustowicz theory was influential in predicting coefficient $B$. Sałustowicz [16] assumed that the rock mass above the mined-out deposit is a homogeneous, isotropic and linear elastic me-

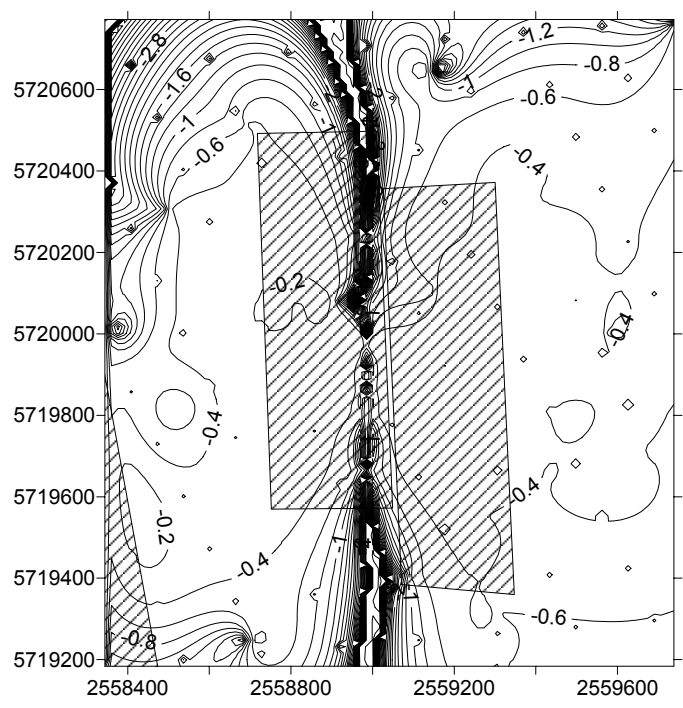

Fig. 1. The distribution of horizontal deformation coefficients in standardized system $B(z) / r$ or $D(z) / r$ in the exploitation area of the logwall panels 698 and 697 in the seam $\mathrm{O} / \mathrm{N}$ of Prospel-Haniel Mine

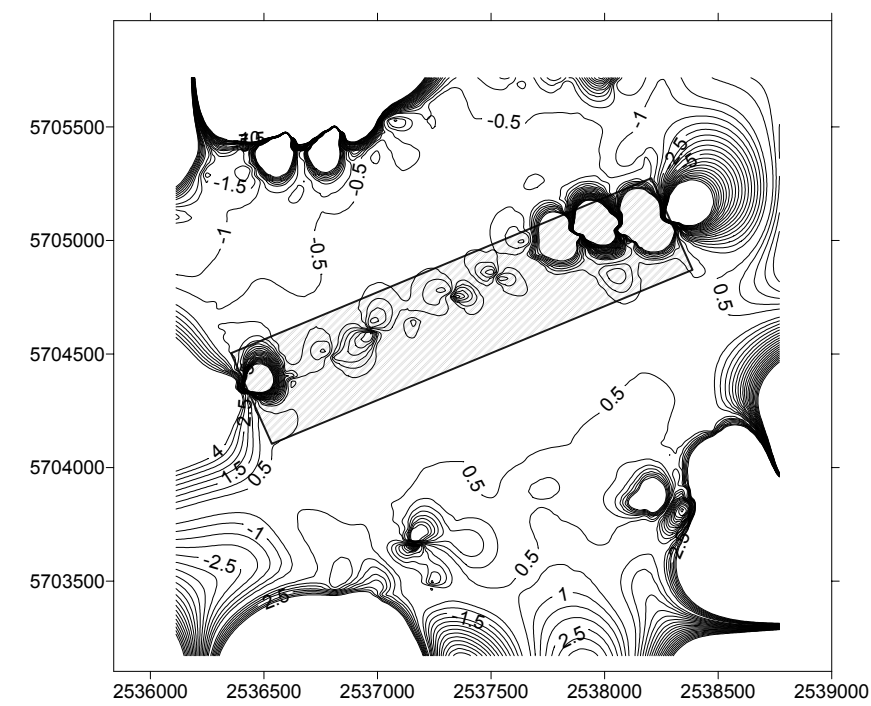

Fig. 2. The distribution of horizontal deformation coefficients in standardized system $B(z) / r$ or $D(z) / r$ in the exploitation area of the longwall panel 537 in the seam Girondelle 5 of Friedrich Heinrich/Rheinland Mine 
dium. He argued that the behavior of the bending overburden may be described with the use of elastic plate resting on elastic (Winkler-type) foundation.

In order to estimate the influence of underground exploitation on the surface buildings one should pay particular attention to the following elements of the trough created in the surface:

- maximum terrain slope $T_{\max }$,

- maximum terrain curvature $K_{\max }$,

- maximum horizontal displacement $u_{\max }$ and maximum horizontal deformation $\varepsilon_{\max }$.

A comparison of the maximum values of surface deformation, based on the theory of Sałustowicz and Budryk-Knothe theory, obtained for the longwall exploitation of coal deposit with the thickness $g$ at the depth $H$, is presented in Table 1 .

Table 1

\begin{tabular}{|c|c|}
\hline Sałustowicz theory & Budryk-Knothe theory \\
\hline$T_{\max }=0.98 \frac{w_{\max }}{r}$ & $T_{\max }=\frac{w_{\max }}{r}$ \\
\hline$K_{\max }=1.25 \frac{w_{\max }}{r^{2}}$ & $K_{\max }=1.52 \frac{w_{\max }}{r^{2}}$ \\
\hline$\varepsilon_{\max }=1.27 \cdot B \frac{T_{\max }}{r}$ & $\varepsilon_{\max }=1.52 \cdot B \frac{T_{\max }}{r}$ \\
\hline$B^{*}=\frac{r}{\sqrt[4]{2 \pi^{3}}}=0.36 r$ & $B^{*}=\frac{r}{\sqrt{\pi}}=0.56 r$ \\
\hline$\varepsilon_{\max }=0.46 \cdot T_{\max }$ & $\varepsilon_{\max }=0.85 \cdot T_{\max }$ \\
\hline \multicolumn{2}{|c|}{$\begin{array}{l}{ }^{* *} \text { On the basis of the experience for the theory or } \\
\text { Budryk-Knothe and the theory of Salustowicz the fol } \\
\text { lowing value was assumed } \varepsilon_{\max }=0.60 \cdot T_{\max }\end{array}$} \\
\hline $\begin{array}{c}\text { For } \varepsilon_{\max }=0.60 \cdot T_{\max } \\
B=0.47 r \\
u_{\max }=B \cdot T_{\max }\end{array}$ & $\begin{array}{c}\text { For } \varepsilon_{\max }=0.60 \cdot T_{\max } \\
B=0.40 r \\
u_{\max }=B \cdot T_{\max }\end{array}$ \\
\hline $\begin{array}{c}u_{\max }=k \cdot w_{\max } \text { where } \\
k=0.47\end{array}$ & $\begin{array}{c}u_{\max }=k \cdot w_{\max } \text { where } \\
k=0.40\end{array}$ \\
\hline
\end{tabular}

In Table 1 , the value of $B^{*}$ was determined with the use of Avershyn's assumption that $B$ is a distance from the surface to the neutral axis of overburden strata bending as a result of mining. However, a mistake was made while determining the value of $B^{*}$ according to Sałustowicz theory. In the works of Sałustowicz ([6], 1955 p. 277), the value of $B^{*}$ was calculated from an incorrect formula $B^{*}=r^{4} \sqrt{\frac{2}{\pi^{3}}}=0.50 r$; the formula actually should have possessed the form (as in Table 1): $B^{*}=\frac{r}{\sqrt[4]{2 \pi^{3}}}=0.36 r$. As the research studies indicate, the value of $B^{*}=0.36 r$ describes the results of obser- vation much better. The value $B^{*}=\frac{r}{\sqrt{2 \pi}}=0.40 r$ in Budryk-Knothe theory** is a consequence of the assumption that the maximum values of horizontal deformation "usually do not exceed" $\varepsilon_{\max }=0.60 \cdot T_{\max }$ (Budryk [4], [5]).

In the former Soviet Union, numerous research projects were carried out in order to determine the values of horizontal displacement from a recognized vertical displacement and slope. Also there, it was assumed that between the maximum slope and maximum horizontal displacement for $\alpha<20^{\circ}(\alpha-$ seam layer inclination) there is a correlation

$$
u_{\max }=B \cdot T_{\max }
$$

and a correlation

$$
u_{\max }=k \cdot w_{\max } \quad \text { or } \quad k=\frac{u_{\max }}{w_{\max }}
$$

where

maximum subsidence $w_{\max }=a \cdot g,(g-$ deposit thickness, $a$ - exploitation coefficient),

$B$ - horizontal deformation coefficient, which depends upon the geological structure, physical and mechanical properties of rock mass, depth of exploitation and thickness of mined-out deposit,

$k$ - a coefficient describing the relation of maximum horizontal displacement to maximum vertical displacement.

Between the coefficients $\boldsymbol{B}$ and $\boldsymbol{k}$ (for seam exploitation) there is a correlation: $k=\frac{B}{r}$.

On the basis of a considerable number of observations, Akimov [1], [2] argued that the value of coefficient $B$ is equal to a total thickness of Neogene (Quaternary) overburden (non-cohesive soils, gravels, sands, etc.) and Paleogene strata with low strength parameters (weak, fractured rocks), measured from the surface; whereas if such soils and rocks are nonexistent, it is equal to a depth from the surface to one of the boundaries between various layers of rock mass. Akimov assumed that at a certain depth in the rock mass there is a neutral axis, along which horizontal displacement and horizontal deformations are equal to zero. The works of Akimov are a consequence of the hypothesis assumed first by Avershyn, and later by Sałustowicz, also supported by numerous observations, that during the exploitation at a considerable depth, rock strata above the caving zone and the fracture zone deform in a similar way as the upper layer of bended beam (above the neutral axis). Dymek ([8]) applied the concept of elastic half-plane for the 
Table 2

\begin{tabular}{|c|c|c|c|c|c|c|}
\hline $\begin{array}{l}\text { Name of } \\
\text { coal basin }\end{array}$ & $\begin{array}{c}\text { Average strength } \\
\text { parameters of } \\
\text { overburden rock }\end{array}$ & $a$ & $T_{\max }$ & $\begin{array}{l}\text { Neogene } \\
\text { thickness }\end{array}$ & $k$ & Comments \\
\hline Donetsk & $R_{c}=96 \mathrm{MPa}$ & 0.70 & $T_{\max }=1.60 \frac{g}{H}$ & & 0.30 & $\begin{array}{l}\text { Depth of exploitation } \\
600<H<1000 \mathrm{~m}\end{array}$ \\
\hline Lviv - Volyn & $R_{c}=25 \mathrm{MPa}$ & 0.80 & $T_{\max }=1.40 \frac{g}{H}$ & approx. $20 \mathrm{~m}$ & 0.34 & $\begin{array}{c}\text { Average depth of } \\
\text { exploitation } H<500 \mathrm{~m}\end{array}$ \\
\hline Kuznetsk & $R_{c}=38 \mathrm{MPa}$ & 0.70 & $T_{\max }=1.70 \frac{g}{H}$ & $35 m-75 m$ & 0.24 & $\begin{array}{c}\text { Low-depth exploitation } \\
H<150 \mathrm{~m}\end{array}$ \\
\hline \multirow{3}{*}{ Karaganda } & $\begin{array}{c}\text { Average-strong } \\
\text { overburden } \\
R_{c}=50 \mathrm{MPa} \\
\end{array}$ & 0.65 & $T_{\max }=1.55 \frac{g}{H}$ & approx. $10 \mathrm{~m}$ & 0.30 & \\
\hline & $\begin{array}{c}\text { Average overburden } \\
R_{c}=30 \mathrm{MPa}\end{array}$ & 0.75 & $T_{\max }=1.55 \frac{g}{H}$ & approx. $10 \mathrm{~m}$ & 0.30 & \\
\hline & $\begin{array}{c}\text { Weak overburden } \\
R_{c}=20 \mathrm{MPa}\end{array}$ & 0.80 & $T_{\max }=1.55 \frac{g}{H}$ & approx. $10 \mathrm{~m}$ & 0.30 & \\
\hline Kizelovsk & $\begin{array}{c}\text { Strong overburden } \\
R_{c}=110 \mathrm{MPa}\end{array}$ & 0.70 & $T_{\max }=1.60 \frac{g}{H}$ & $5 m-20 m$ & 0.30 & \\
\hline $\begin{array}{l}\text { Pechora } \\
\text { (Vorkuta, } \\
\text { Vorgashorskaya) }\end{array}$ & $\begin{array}{c}\text { Strong overburden } \\
R_{c}=70 \mathrm{MPa}\end{array}$ & 0.65 & $T_{\max }=1.60 \frac{\mathrm{g}}{\mathrm{H}}$ & $100 m-120 m$ & $\begin{array}{l}0.30 \\
0.58\end{array}$ & $\begin{array}{c}\text { for } \\
\vartheta=\frac{h_{m}}{H_{g}}=0.70 \\
\text { for } \\
\vartheta=\frac{h_{m}}{H_{g}}=0.90\end{array}$ \\
\hline Chelyabinsk & $\begin{array}{c}\text { Weak overburden } \\
R_{c}=20 \mathrm{MPa}\end{array}$ & 0.85 & $T_{\max }=1.20 \frac{g}{H}$ & $100 m-120 m$ & 0.35 & \\
\hline Northern (France) & - & 0.88 & $T_{\max }=1.25 \frac{g}{H}$ & - & 0.40 & \\
\hline Ruhr (Germany) & - & 0.90 & $T_{\max }=1.20 \frac{g}{H}$ & - & 0.40 & \\
\hline Limberg (Holland) & - & 0.90 & $T_{\max }=1.10 \frac{g}{H}$ & - & 0.44 & \\
\hline
\end{tabular}

determination of the state of displacement above a excavated long drift with the width of $2 b$. Ryncarz [15] adapted this solution to the exploitation of a horizontal seam. An analysis of the obtained data indicates that the horizontal displacements above the edge of the deposit are constant and do not depend on depth, whereas they depend on the value of Poisson's ratio $v, u_{\max }=-\frac{w_{\max }}{\pi(3-4 v)}$. In this solution, the value of coefficient $B$ is $B=\frac{H}{4(1-v)}$, hence the value of $B$ ranges between $0.25 \mathrm{H}$ and $0.50 \mathrm{H}$.

Much later, in the mid-1970s, Drzęźla [7], using the approximate solution of the elasticity theory formulae to the rock mass in flat state of strain, in which a horizontal deposit drift of an infinite length was mined out, arrived at the formulae describing rock mass movements qualitatively, similarly to the ones assumed by Avershyn. Comparable results are obtained if an elastic model is assumed for the rock mass in numerical methods. It is, therefore, highly probable that in the rock mass there is a neutral axis, just like in the bended beams [3], [19].

The values of maximum slope $T_{\max }$, subsidence factor $a$, coefficient $k$ for seven coal basins of the former Soviet Union [1], [2], as well as the coal basins in Germany, France and Holland [18], are presented in Table 2.

The value of subsidence factor $a$ for the exploitation executed with roof rock caving seriously depends upon the physical and mechanical properties of strata constituting the overburden, in particular their strength parameters. For the overburden with rock strata of average and high compression strength, in brief referred to as an "average overburden" or a "strong overburden", the subsidence factor equals $a=0.65$ during the first exploitation, whereas with further exploitations in a given area it rises to the value of $a=0.80-0.85$. However, for the overburden with rock strata of low compressive strength, in brief referred to as a "weak 
overburden", the subsidence factor equals $a=0.80$ during the first exploitation, whereas with further exploitations in a given area it increases to the value of $a=0.90$.

The values of coefficient $k$, and thereby of coefficient $B$, are predominantly affected by the following factors:

- physical and mechanical properties of rock strata constituting overburden, especially their strength parameters,

- exploitation depth $H$,

- thickness of Neogene (mainly soils) and Paleogene (Tertiary) layers with low strength $h_{m}$, especially the relation $\vartheta=\frac{h_{m}}{H_{g}}$, of the thickness $h_{m}$ (of "weak layers") to the thickness of the entire overburden $H$ diminished by the caving zone $h_{z}$ and the fracture zone $h_{s}\left(H_{g}=H-h_{z}-h_{s}\right)$. Akimov [2] noticed that if the considerably thick Paleogene and Neogene layers of low strength occur above the mined-out deposit, the volume of horizontal displacement, slope, curvature and horizontal deformation is larger than in the case when the "weak layers" constitute only a small fraction of the total overburden thickness $H_{g}$. The volume of $k$ ranges between 0.30 and 0.58 , depending upon the relationship $\vartheta=\frac{h_{m}}{H_{g}}$. If in the overburden of the exploited deposit the relation is $\vartheta=\frac{h_{m}}{H_{g}}=$ 0.90 , then $k=0.58$. If the thickness of weak Neogene layers and "weak" Paleogene layers in the overburden diminishes and, at the same time, the ratio of stronger rocks of mainly carbonate group increases, then the coefficient $k$ decreases linearly, and at the value $\vartheta=\frac{h_{m}}{H_{g}} \leq 0.70$ it is set at the level of $k=0.3$. A linear decrease of coefficient $k$ from the value of 0.58 to the value of 0.30 can be described by means of the correlation $k=1.40 \cdot \vartheta-0.68$.

In general, the correlation of the factor $a$ and coefficient $k$ (after the completion of exploitation and at horizontal deposition of the seam) with the average overburden strength can be described according to Table 3 (Akimov et al. [2]):

The fact that the value of coefficient $B$ and correlation between horizontal and vertical displacement $k$, as well as factor $a$, depend on the depth of exploitation, geological structure and type of rocks, is well documented by the results of measurements and calculations obtained for Polish sulphur mines of "Jeziórka", "Grzybowa", "Machowa II" and "Osieka". Sulphur is deposited at a small depth, hence the average depth of sulphur deposit exploitation ranges between $100 \mathrm{~m}$ and $134 \mathrm{~m}$. The overburden of sulphur mines is fairly homogeneous and consists of (respectively from the surface): more than 10-meter thick Neogene formations, Krakowiec clays with the thickness of $80 \mathrm{~m}$ to $120 \mathrm{~m}$ with sandy inclusions, whose ratio is significant (reaching 25\%) and more than 10 -meter thick Pecten layers. The Krakowiec clays possess strong elastic-viscous-plastic properties, whereas the Pecten layers are less deformable and possess higher strength than Krakowiec clays, however they tend to be fractured, especially in the vicinity of sulphur deposit.

Table 3

\begin{tabular}{|l|c|c|c|c|}
\hline \multicolumn{1}{|c|}{ Average strength of overburden rock strata } & \multicolumn{2}{c|}{ First exploitation } & \multicolumn{2}{c|}{ Further exploitations } \\
\cline { 2 - 5 } & $a$ & $K$ & $a$ & $k$ \\
\hline Prevailing weak rocks $R_{c} \leq 25 \mathrm{MPa}$ & 0.85 & 0.35 & 0.9 & 0.35 \\
\hline $\begin{array}{l}\text { Rocks of average cohesion and strong } R_{c} \text { from } 25 \mathrm{MPa} \\
\text { to } 80 \mathrm{MPa} \text { and more }\end{array}$ & 0.75 & 0.30 & 0.85 & 0.30 \\
\hline
\end{tabular}

Table 4

\begin{tabular}{|c|c|c|c|c|c|c|c|c|}
\hline \multirow[t]{2}{*}{$\begin{array}{l}\text { Sulphur } \\
\text { mine }\end{array}$} & \multicolumn{2}{|c|}{$\begin{array}{c}\text { Average thickness } \\
\text { of Neogene } H_{c} \\
\text { and Paleogene } H_{t}\end{array}$} & \multirow{2}{*}{$\begin{array}{c}\text { Average depth } \\
\text { of } \\
\text { exploitation } \\
H \\
\end{array}$} & \multicolumn{2}{|c|}{$\begin{array}{l}\text { Range of main } \\
\text { influences }\end{array}$} & \multirow[t]{2}{*}{$r[\mathrm{~m}]$} & \multirow{2}{*}{\multicolumn{2}{|c|}{$\begin{array}{l}\text { Horizontal deformation } \\
\text { coefficients } B \text { and } k\end{array}$}} \\
\hline & $H_{c}[\mathrm{~m}]$ & $H_{t}[\mathrm{~m}]$ & & $\beta$ & $\tan \beta$ & & & \\
\hline Jeziórko & 12 & 120 & 134 & $53.4^{\circ}$ & 1.36 & 105.5 & $B=0.15 r$ & $k=0.15$ \\
\hline Grzybów & 10 & 120 & 130 & $58.0^{\circ}$ & 1.58 & 88.0 & - & - \\
\hline Machów II & 8 & 88 & 100 & $51.0^{\circ}$ & 1.23 & 81.1 & $B=0.26 r$ & $k=0.26$ \\
\hline Osiek & 12 & 102 & 114 & $53.0^{\circ}$ & 1.33 & 71.1 & $B=0.32 r^{*}$ & $k=0.32 *$ \\
\hline
\end{tabular}

* The value of $B$ was assumed as in Popiołek and Ostrowski [14]. 
Table 5

\begin{tabular}{|l|c|l|}
\hline \multicolumn{1}{|c|}{ Author } & Year of publication & \multicolumn{1}{|c|}{ Value of parameter $B$} \\
\hline Budryk & 1953 & $\begin{array}{l}\text { B }=\frac{r}{\sqrt{\pi}}=0.56 r \text { for } \varepsilon_{\max }=0.85 \cdot T_{\max } \\
B=\frac{r}{\sqrt{2 \pi}}=0.40 r \text { for } \varepsilon_{\max }=0.60 \cdot T_{\max }\end{array}$ \\
\hline Sałustowicz & 1953 & $B=\frac{r}{\sqrt[4]{2 \pi^{3}}}=0.36 r$ for $\varepsilon_{\max }=0.46 \cdot T_{\max }$ \\
\hline Avershyn & 1954 & $B=0.47 r$ for $\varepsilon_{\max }=0.60 \cdot T_{\max }$ \\
\hline Akimov et al. & 1970 & $B=(0.15-0.18) H$ \\
\hline Popiołek, Ostrowski & 1978 & $B=\frac{0.156 \cdot H-17) r \text { average } B=0.30 r}{1-53.7 \cdot T_{\max }}$ \\
\hline Niemiec, Radoła & 1981 & $B=0.16 H \cong 0.32 r$ for tan $\beta=2.0$ \\
\hline Kratzsch & 1983 & $B=0.33 r$ \\
\hline Niedojadło & 1984 & For $-\infty<x \leq b, B(x)=\frac{B}{b^{2}(x-2 b x)}$ \\
\hline Sroka & 1995 & For $b<x<\infty, B(x)=\frac{B(b)}{r^{2}}\left[(x-b)^{2}-r^{2}\right]$ \\
\hline Szpetkowski & & $B=(0.15-0.70) r$ \\
\hline Xueyi Yu, Niedbalski & 1998 & $B=0.80 \frac{r^{2}}{H}$ \\
\hline
\end{tabular}

Flisiak et al. [9] analyzed the selection of parameters of Budryk-Knothe theory for sulphur mines. The results of their research are presented in Table 4.

It may be observed that at a small depth of exploitation in sulphur mines, the obtained value of coefficient $k$ is similar to the one obtained in Kuznetsk Coal Basin (cf. Table 2, $k=0.24$ ).

Over the years, the value of parameter $B$ has been estimated by numerous researchers. Table 5 presents some of the hitherto proposed methods of estimating the value of $B$ (cf. also Hejmanowski and Kwinta [10]).

In general, Table 5 confirms the results obtained by Akimov et al. [2], suggesting that the value of parameter $B$ depends on the depth $H$ and the radius of main influence range $r$, which is in turn seriously affected by the properties of rocks occurring in the overburden, especially the occurrence of Paleogene and Neogene layers with low strength.

\section{ESTIMATING THE INFLUENCE OF PALEOGENE AND NEOGENE LAYERS WITH LOW STRENGTH ON THE VALUE OF COEFFICIENT $B$}

The reliance of parameter $B$ upon the occurrence of Neogene layers (sands, gravels, clays, etc.) and

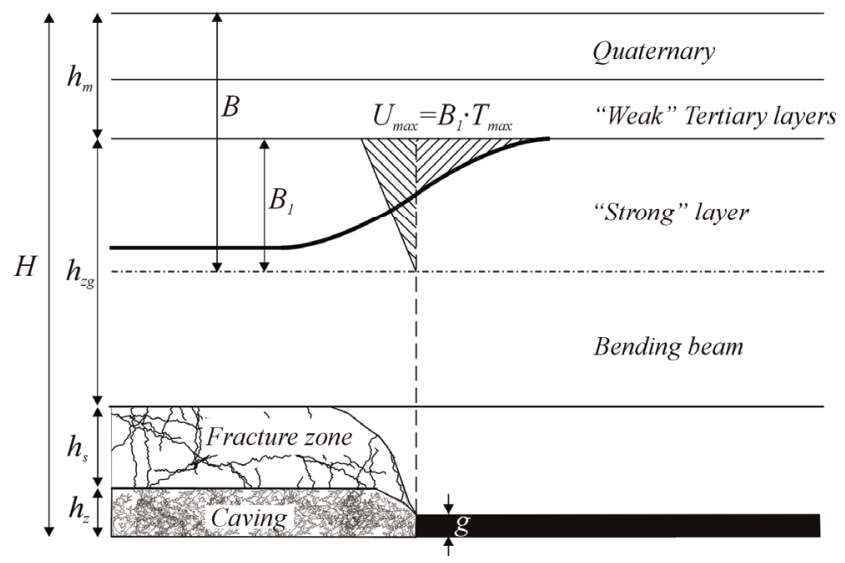

Fig. 3. Bended layer with appropriately high strength parameters ("strong" layer)

Paleogene layers with low strength may be simply described with the use of the good old, today underestimated, theory of Sałustowicz [16]. Sałustowicz assumed that in the overburden of exploited seam, a thick rock layer may be distinguished, which is subject to bending as a result of deformation. The behavior of this layer was described by means of elastic plate resting on elastic (Winkler-type) foundation. A question arises here: where is this layer and what is its thickness? It should be a layer above caving and fracture zones, possessing at the same time appropriately large strength not to be destroyed (fractured) as a result of mining-induced deformations. 
Therefore, the layer should be situated below the Paleogene and Neogene strata with low strength. Figure 3 presents a schematic situation of the bended layer. Sałustowicz analyzed only the bending of the beam without any other layers as if the bending beam reached from the deposit to the surface. Hence, the value of $B$ obtained in such a way was the distance between the surface and the neutral axis of the beam. In such conditions, Sałustowicz obtained (after correcting the mistake) $B^{*}=\frac{r}{\sqrt[4]{2 \pi^{3}}}=0.36 r$. In this case, $r=r_{1}$.

If we assume the occurrence of Paleogene and Neogene layers with low strength, as well as fracture and caving zones, then after simple considerations we may conclude that half of the thickness of the bending beam $B_{1}$ may be calculated from the following formula

$$
B_{1}=0.36 \cdot r_{1}=0.36 \cdot \cot \beta \cdot\left(H-h_{m}-h_{s}-h_{z}\right),
$$

where

$r_{1}$ - range of main influences estimated along the beam,

$h_{m}$ - thickness of Paleogene and Neogene strata with low strength parameters,

$h_{s}$ - height of fracture zone,

$h_{z}-$ height of caving zone.

$$
B=h_{m}+0.36 \cdot \cot \beta \cdot\left(H-h_{m}-h_{s}-h_{z}\right)
$$

or

$$
B=\left\{0.36+\frac{1}{H}\left[h_{m}(\tan \beta-0.36)\right]-0.36\left(h_{s}+h_{z}\right)\right\} \cdot r
$$

As $k=\frac{B}{r}$, therefore

$$
k=0.36+\frac{1}{H}\left[h_{m}(\tan \beta-0.36)\right]-0.36\left(h_{s}+h_{z}\right) .
$$

\section{Example 1}

The influence of total thickness of Paleogene and Neogene with low strength parameters ("weak" layer) on the values of coefficients $B$ and $k$ (cf. Table 6).

It was assumed that $\tan \beta=2.0$ and the depth of exploitation is $H=600 \mathrm{~m}$, caving zone is equal to fracture zone $h_{z}=h_{s}=5 g(g=3.0 \mathrm{~m})$, therefore $h_{z}+h_{s}=30 \mathrm{~m}$. Comparative calculations were carried out, in which first the heights of fracture zone $h_{s}$ and caving zone $h_{z}$ were not taken into consideration, and in later calculations these zones were considered.

\section{Example 2}

The influence of the height of caving zone and fracture zone on the values of coefficients $k$ and $B$ (cf. Table 7).

The obtained values of coefficients $k$ and $B$ are slightly overstated as Sałustowicz analyzed the socalled "thin" beam on elastic foundation, which is subject only to bending. If we consider the so-called "thick" beam in our calculations, we also need to assume the shear forces. Taking the shear forces into consideration causes the decrease of the values of $k$ and $B$. Table 4 (cf. also Flisiak et al. [9]) presents the parameters of Budryk-Knothe theory for sulphur mines obtained on the basis of long-term observations. Taking these results into consideration, by means of

Table 6

\begin{tabular}{|c|c|c|c|c|}
\hline Thickness of "weak" layer & \multicolumn{2}{|c|}{ Value of coefficient $k$} & \multicolumn{2}{c|}{ Value of coefficient $B$} \\
\cline { 2 - 5 } $\begin{array}{c}\text { (Paleogene and Neogene with } \\
\text { low strength parameters) }\end{array}$ & $\begin{array}{c}\text { Without caving and } \\
\text { fracture zones }\end{array}$ & $\begin{array}{c}\text { With caving and } \\
\text { fracture zones }\end{array}$ & $\begin{array}{c}\text { Without caving and } \\
\text { fracture zones }\end{array}$ & $\begin{array}{c}\text { With caving and } \\
\text { fracture zones }\end{array}$ \\
\hline$h_{m}=0 \mathrm{~m}$ & $k=0.36$ & $k=0.36$ & $B=0.36 r$ & $B=0.36 r$ \\
\hline$h_{m}=20 \mathrm{~m}$ & $k=0.41$ & $k=0.4$ & $B=0.41 r$ & $B=0.40 r$ \\
\hline$h_{m}=40 \mathrm{~m}$ & $k=0.47$ & $k=0.45$ & $B=0.47 r$ & $B=0.45 r$ \\
\hline$h_{m}=60 \mathrm{~m}$ & $k=0.52$ & $k=0.50$ & $B=0.52 r$ & $B=0.50 r$ \\
\hline$h_{m}=80 \mathrm{~m}$ & $k=0.58$ & $k=0.56$ & $B=0.58 r$ & $B=0.56 r$ \\
\hline
\end{tabular}

Table 7

\begin{tabular}{|c|c|c|c|}
\hline $\begin{array}{c}\text { Height of caving } \\
\text { and fracture zones }\end{array}$ & $\begin{array}{c}\text { Thickness } \\
\text { of "weak" layer }\end{array}$ & $\begin{array}{c}\text { Value } \\
\text { of coefficient } k\end{array}$ & $\begin{array}{c}\text { Value } \\
\text { of coefficient } B\end{array}$ \\
\hline$h_{s}+h_{z}=0 \mathrm{~m}$ & $10 \mathrm{~m}$ & 0.39 & $0.39 r$ \\
\hline$h_{s}+h_{z}=30 \mathrm{~m}$ & $10 \mathrm{~m}$ & 0.37 & $0.37 r$ \\
\hline$h_{s}+h_{z}=60 \mathrm{~m}$ & $10 \mathrm{~m}$ & 0.35 & $0.35 r$ \\
\hline$h_{s}+h_{z}=90 \mathrm{~m}$ & $10 \mathrm{~m}$ & 0.33 & $0.33 r$ \\
\hline$h_{s}+h_{z}=120 \mathrm{~m}$ & $10 \mathrm{~m}$ & 0.31 & $0.31 r$ \\
\hline
\end{tabular}


a reverse analysis we can determine the thickness of the bended beam in the conditions of sulphur exploitation. For instance, for the mine Machów II, after inserting the data: $h_{m}=8 \mathrm{~m}, \tan \beta=1.23, H=100 \mathrm{~m}$, $B=0.26 r$, from formula (7) we obtain the result that the fracture zone (in the conditions of sulphur mining, a typical caving does not exist, there is however a high fracture zone) above the mined-out deposit is approx. $47 \mathrm{~m}$, which means that the thickness of the bended beam is approx. $45 \mathrm{~m}$.

\section{CONCLUSIONS}

(1) Survey measurements of completely shaped subsidence troughs prove that the value of coefficient $B$ (i.e., the value determining the relation of maximum horizontal displacement to maximum slope of subsidence trough profile) depends on the depth $H$ and the radius of main influence range $r$, which is in turn seriously affected by the properties of rocks occurring in the overburden, especially by the occurrence of Paleogene and Neogene layers with low strength.

(2) In most cases, the value of parameter $B$ ranges between: $0.3 \cdot r \leq B \leq 0.4 \cdot r$.

(3) Along with the increase of the thickness of Paleogene and Neogene layers with low strength parameters, also the value of coefficient $B$ rises, whereas along with the increase of caving zone and fracture zone, the coefficient decreases. The impact of the thickness of Paleogene and Neogene layers with low strength parameters, as well as of caving and fracture zones, can be estimated with the use of formula (7).

\section{ACKNOWLEDGMENT}

The project was financed from the funds of National Science Center granted under the decision No. DEC - 2011/01/D/ST8/07280.

\section{REFERENCES}

[1] AкIMOV A.G., $K$ raschetu naibolshikh gorizontalnykh sdvizhenii zemnoi poverkhnosti pri razrabotke pologikh plastov, Trudy VNIMI, sb. XXXIV, Gosgortekhizdat, 1960.

[2] AKImov A.G. et al., Sdvizhenie gornykh porod pri podzemnoi razrabotke ugolnykh i slancevykh mestorozhdenii, Nedra Publishers, Moscow 1970.
[3] Alejano L.R., Ramirez-Oyanguren P., Taboada J., FDM predictive methodology for subsidence due to flat and inclined seam mining, Int. J. Rock Mech. Min. Sci., 1999, 36(4), 475-491.

[4] BUDRYK W., Obliczanie sposobu podziemnej eksploatacji pod obiektami na powierzchni, Przegląd Górniczy, 1952, No. 7-8.

[5] BUDRYK W., Wyznaczanie wielkości poziomych odkształceń terenu, Archiwum Górnictwa i Hutnictwa, PWN, Kwartalnik, Warszawa, 1953, Vol. 1, b. 1.

[6] Avershyn S.G., Sdwizhenie gornykh parod pri podzemnykh razrabotkakh, Ugletechizdat, Moskva 1948.

[7] DRzĘźLA B., Przybliżone rozwiazanie równań teorii sprężystości w zastosowaniu do mechaniki górotworu, Archiwum Górnictwa, 1975, Vol. XX, b. 2.

[8] DyмeK F., Przemieszczeniowe zadanie brzegowe przestrzennej teorii sprężystości i jego zastosowanie do zagadnień mechaniki górotworu, 1969, Vol. 14, b. 3.

[9] FlisiaK J., MazureK J., TAJdús A., Wyznaczanie parametrów teorii Budryka-Knothego dla polskich kopalń siarki, ZN AGH, Górnictwo, 1992, 16, b. 4,

[10] Hejmanowski R., Kwinta A., Determining the coefficient of horizontal displacements with the use of orthogonal polynomials, Arch. Min. Sci., 2009, Vol. 54, 441-454.

[11] KNOTHE S., SROKA A., Stochastyczna ocena wptywu eksploatacji na obiekty budowlane $w$ procesie planowania eksploatacji górniczej, 2nd Conference "Bezpieczeństwo i ochrona obiektów budowlanych na terenach górniczych", UstronZawodzie, 4-6 October 2010, Główny Instytut Górnictwa Katowice, 2010, 155-173.

[12] Kratzch H., Mining subsidence engineering, SpringerVerlag, Berlin, 1983.

[13] Litwiniszyn J., Równanie różniczkowe przemieszczeń górotworu, Archiwum Górnictwa i Hutnictwa, 1953, Vol. 1, b. 1.

[14] Popiolek E., Ostrowski J., Zależność między nachyleniami a przemieszczeniami poziomymi terenu $w$ ostatecznie wyksztatconych nieckach osiadania, Ochrona Terenów Górniczych, 1978, No. 46.

[15] RYNCARZ T., Ruchy górotworu wywołane wyrobiskami podziemnymi, Skrypty Uczelniane No. 1295, Wydawnictwa AGH, Kraków 1992.

[16] Salustowicz A., Profil niecki osiadania jako ugięcie warstwy na sprężystym podłożu, Archiwum Górnictwa i Hutnictwa, 1953, Vol. 1, b. 1.

[17] SzPETKOwSKI S., Prognozowanie wpływów eksploatacji złóż pokładowych na górotwór $i$ powierzchnię terenu, Śląskie Wydawnictwa Techniczne, Katowice, 1995.

[18] Tandanand S., Powell L.R., Determining Horizontal Displacement and Strains Due to Subsidence, Report of Investigations 9358 United States Department of the Interior, Bureau of Mines, 1991.

[19] TAJDUŚ K., Numerical simulation of Underground Mining Exploitation influence upon terrain surface, Arch. Min. Sci., 2013, Vol. 58, 605-616.

[20] Salustowicz A., Mechanika górotworu, Wydawnictwo Górniczo-Hutnicze, 1955. 